Tyndale Bulletin 65.1 (2014) 11-19

\title{
THE DELIVERANCE OF RAHAB (JOSHUA 2, 6) AS THE GENTILE EXODUS
}

Nicholas P. Lunn

\begin{abstract}
Summary
This short article argues for an intertextual interpretation of the Rahab narratives in the book of Joshua in the light of the deliverance of the Hebrews from Egypt as recorded in the book of Exodus. The presence of a range of different verbal and thematic correspondences supports such a notion. This is further confirmed once a structural parallelism between the two portions of text is identified. Suggestions are given as to what the relationship was designed to indicate.
\end{abstract}

\section{Introduction}

Literary studies of biblical texts have brought to light many instances in which it appears that a text in one part of the Hebrew canon may be seen to have been intended to interact with another text elsewhere in the canon. This is the phenomenon commonly termed 'intertextuality'. ${ }^{1}$ Studies in recent decades have brought to light numerous examples of this literary feature, some of which are now so commonly referenced that they have almost become case examples. Amongst these latter may be included the interaction between Judges 19 relating matters of hospitality and $\sin$ in connection with Gibeah, and Genesis 19 concerning the sin of Sodom and hospitality of Lot. ${ }^{2}$ Such textual

1 For a survey of the latest study and the issues involved, see Geoffrey D. Miller, 'Intertextuality in Old Testament Research', Currents in Biblical Research 9.3 (2011): 283-309.

2 The earliest published source for this comparison seems to have been Stuart Lasine, 'Guest and Host in Judges 19: Lot's Hospitality in an Inverted World', JSOT 29 (1984): 37-59. It has since been taken up by commentators, such as Victor H. Matthews, Judges and Ruth (New Cambridge Bible Commentary; Cambridge: Cambridge University Press, 2004): 183-90; Tammi J. Schneider, Judges (Berit Olam; 
interaction of course plays a role in interpretation. When the actions of an Israelite town in Judges are compared with Sodom in Genesis the implications are not inconsequential. Rather there is an important, though implicit, statement on the part of the author upon the spiritual condition of the nation at the time of the judges. ${ }^{3}$ Another reasonably apparent example is the relationship between 1 Kings 12 where Jeroboam makes calf idols for Israel to worship and Exodus 32 regarding the worship of the golden calf. ${ }^{4}$

This paper identifies another such intertextual relationship between two portions of the Old Testament. These are on one hand those passages in Judges concerned with Rahab and the fall of Jericho, found principally in chapters 2 and 6 , and on the other hand the account of the departure of Israel from Egypt. The former of these are found principally in chapters 2 and 5-6 of the book of Joshua. Although separated by the narratives treating the crossing of the Jordan, these sections are evidently closely related parts of a whole, the earlier chapter being preparatory for the later events of Jericho's downfall and the deliverance of Rahab. These are compared with the narratives contained in Exodus chapters 12-15. First, the existence of a correspondence or an intentional parallel will be established through the presentation of a series of linkages or correspondences in language and subject matter. This will then be further corroborated through structural considerations. Finally, the question of what the intertextual relationship is intended to convey will be briefly treated.

At the outset it needs to be emphasised that for the present purposes the relative dating of the books of Exodus and Joshua is immaterial. Even if the former were composed at a later date, it can hardly be doubted that it was based upon earlier sources, whether written or oral.

Collegeville, Minnesota: Liturgical Press, 2000): 260-62; Daniel I. Block, Judges, Ruth (New American Commentary; Nashville, Tennessee: Broadman \& Holman, 1999): 520-21, 532-34.

3 Cf. Block, Judges, Ruth: 544, where the comment is made: 'By patterning this account after the earlier story, the narrator serves notice that, whereas these travelers had thought they had come home, finding safety with their own countrymen, they have actually arrived in Sodom. The nation has come full circle. The Canaanization of Israel is complete'.

4 Stuart Lasine, 'Reading Jeroboam's Intentions: Intertextuality, Rhetoric, and History in 1 Kings 12', in Danna Nolan Fewell (ed.), Reading Between Texts: Intertextuality and the Hebrew Bible (Louisville, Kentucky: Westminster/John Knox, 1992): 133-52. 


\section{Verbal and Thematic Parallels}

There exists a whole series of correspondences in both words and ideas between the two portions of text. While some of these have been previously documented, for the most part they have passed unnoticed. These points of literary contact are both extensive and diverse. Those of which the present writer is aware are as follows:

(1) One of the most obvious circumstantial connections between the two accounts is that both are linked to occur at Passover time. The Hebrew exodus of course provides the origin of this feast (Exod. 12:21). While the book of Joshua places the actual fall of Jericho some days after the Passover itself, the narrative associates the two through its presentation of records of the first Paschal celebration of the Passover in the promised land (Josh. 5:10) as an event immediately preceding the advance upon Jericho (cf. 5:13). Not only this, both contexts speak of circumcision in connection with keeping the Passover. The former text twice stresses that all males had to be circumcised in order to eat the lamb (Exod. 12:44, 48). The latter text describes the circumcision of the new generation of Hebrew males before they were able to participate in the feast (Josh. 5:2-8). Exodus and Joshua temporally locate the Passover meal by means of precisely the same time phrase: 'on the fourteenth day of the month in the

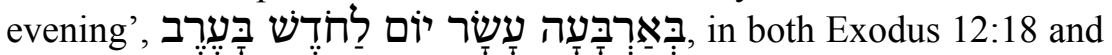

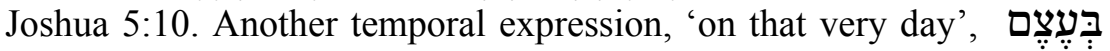
הַיוֹם הַ: also appears in each context (Exod. 12:17, 41, 51; Josh. $5: 11$ ), arguably with the same reference in both, that is, to the first day of Unleavened Bread, a seven-day observance which commenced on the fifteenth of Nisan (Lev. 23:6; cf. Exod. 12:18-19). ${ }^{5}$ The two texts likewise mention the 'unleavened loaves' (מַצוֹת) consumed at this time (Exod. 12:8, 15, 17, 18, 20; Josh. 5:11). ${ }^{6}$

5 The fact that the 14th day of the month is now completed and the feast is one of seven days with the evening of the 21st marking its close, demands that even in Exodus 12 it is the 15th Nisan, and not the 14th, that is the first day of the feast of Unleavened Bread. This, we understand, is the day being referred to in Joshua 5:11. Cf. Michael Fishbane, Biblical Interpretation in Ancient Israel (Oxford: Clarendon, 1985): $148-49$.

6 Passover was held in the spring, the time of the flax harvest, which receives a

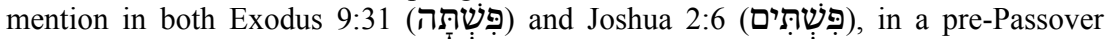
setting. These are in fact the only two places in the entire corpus of the Pentateuch and historical books, excluding the verbal simile in Judges 15:14, in which the actual item 'flax' occurs as a feature in the narrative. 
(2) Both leaders of the people received a prior visitation by an angelic figure. Before his return to Egypt Moses saw the angel in the bush (Exod. 3:1-6). On the eve of the attack upon Jericho Joshua had his own theophanic encounter (Josh. 5:13-15). The second of the two accounts necessarily brings to mind the first through the virtual repetition of the angel's words, 'Remove the sandals from off your feet, for the place where you are standing is holy [ground]' (Exod. 3:5; Josh. 5:15). ${ }^{7}$

(3) In both cases those delivered are preserved in similar ways. Each speaks of how the family is to be gathered into the house where they will be protected from the coming destruction (Exod. 12:27; Josh. 2:18; cf. 6:17).

(4) In each narrative a warning is given about going outside the house (Exod. 12:22; Josh. 2:19).

(5) One important feature is that an external sign is required on each occasion to set apart the houses of those being protected. In the case of the exodus the distinguishing mark is the blood of a lamb, while in Rahab's it is a scarlet cord. The former was applied to the door-frame (Exod. 12:7), the latter attached to the window (Josh. 2:18, 21). In both contexts the Hebrew word for 'sign' (אiא) is used (Exod. 12:13; Josh. $2: 12$ ). In Exodus this specifically indicates the blood. While in the Masoretic text of Joshua 'sign' does not directly refer to the scarlet cord, the LXX makes this connection explicit (Josh. 2:18 LXX, 'You shall set a sign; you shall bind this scarlet cord in the window'). It would appear that the Masoretic text is defective at this point through the error of haplography, ${ }^{8}$ in which case both texts would explicitly designate a particular sign. Certain recent commentators likewise understand the scarlet cord to be a sign comparable to the blood of the Passover lamb. ${ }^{9}$ Furthermore, an obvious semantic connection exists

7 Both angelic appearances are also introduced by the same formula, 'he saw, and

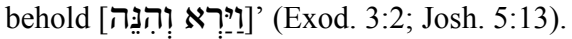

8 Robert G. Boling and G. Ernest Wright, Joshua: A New Translation with Introduction and Commentary (Anchor Bible; New York: Doubleday, 1982): 142.

9 See David M. Howard, Joshua: An Exegetical and Theological Exposition of Scripture (New American Commentary; Nashville, Tennessee: Broadman \& Holman, 1998): 116-17. Howard speaks of an association between Rahab's cord and the Passover. He writes: 'There, the Israelites were to be protected by painting the blood on the doorposts and lintels of their homes as a sign for the Lord as he went through the land to destroy the Egyptians (Exod. 12:13, 22-23). Likewise, Rahab's scarlet cord was to be a sign for the Israelites as they entered Jericho to destroy it'. Cf. also Pekka 
between the door and the window to which the respective signs are applied. The term מַשְׁקוֹר, 'lintel', appearing in Exodus (12:7, 22, 23) may denote the lintel of a window as much as that of a door. Closely related words are found elsewhere with reference to windows: חָלוֹני

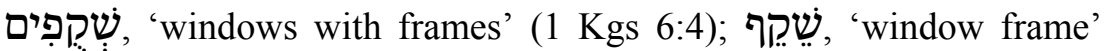
(1 Kgs 7:5). Nor should it be overlooked that in the Rahab narrative the window of her house in fact functions as a door for the two spies (Josh. 2:19). ${ }^{10}$

(6) Each sign has an interesting connection with Hebrew purification rituals. With respect to the blood of the Passover lamb, this was applied to the door-frame by means of אוז 'hyssop' (Exod. 12:22), a species of semi-woody plant. Rahab's cord attached to her window is described as שָָׁ, 'scarlet' (Josh. 2:18, 21). These elements, 'scarlet and hyssop', feature conjointly in the ritual for the cleansing of leprosy (Lev. 14:4, 6; cf. 49, 51, 52) and in the ceremony involving the red heifer (Num. 19:6). It is possible, therefore, that each of the acts carries the connotation of the purification of the household.

(7) Both narratives explicitly view the undertaking in question as a matter of deliverance. Although Hebrew has several verbs that could be used to express this idea, in both cases the same particular word is

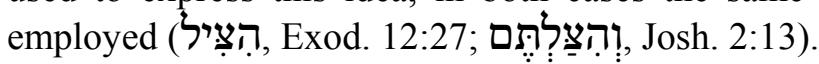

(8) A key term in the exodus context is that verb from which the book of Exodus derives its name in the Christian canon. This is הוֹצִיא, literally 'cause to go out'. This occurs dozens of times throughout the exodus narrative (e.g. Exod. 3:8, 11; 6:6, 26; 7:4; 12:42). The same term also appears in connection with the deliverance of Rahab and her family. In the chapter concerning the overthrow of Jericho it occurs three times in such a usage: 'bring her out' (Josh. 6:22); 'the young men ... brought out Rahab, her father and mother, and all who belonged to her. They brought out the whole of her family ...' (6:23). Rahab and her family, therefore, just like the Hebrews before them, experienced a bringing out, in the one case from the Gentile land of Egypt, in the other from the Canaanite city of Jericho.

M. A. Pitkänen, Joshua (Apollos Old Testament Commentary; Nottingham: Apollos, 2010): 124-25, where the cord is described as a 'symbolic sign'.

10 It might perhaps also be significant that Joshua 2:19 states that anyone passing through the door of the house will incur blood upon their head. Here the terms 'door' and 'blood' bring to mind the details of the original Passover. 
(9) In each instance the bringing out of those who are delivered is enacted upon a previous oath. Though not explicit in the exodus account itself, the fact of a divine oath in force at this time is made evident elsewhere: 'It was because the LORD loved you and kept the oath that he swore to your forefathers, that the LORD has brought you out with a mighty hand and redeemed you from the house of slavery, from the hand of Pharaoh king of Egypt' (Deut. 7:8). Rahab is delivered in accordance with the oath of the two spies (Josh. 2:17; 6:22). Related to this is the fact that in the original exodus (Exod. $15: 13$; cf. 20:6) it is the Lord who acts according to his 'steadfast love' (חסֶ), whereas in Joshua it is the two spies (Josh. 2:12,14).

(10) Both events involve bringing out plunder from the place

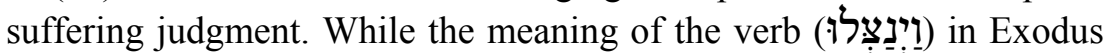
$12: 36$ is not absolutely certain, there is wide agreement that the meaning is 'they plundered the Egyptians' (as, for example, LXX, NRSV, NASB, ESV, NIV; cf. NJB, JPS, 'despoiled'). Whatever the precise sense of the term, the Hebrews are described as taking from Egypt silver, gold, and clothing (Exod. 3:22; 12:35). Following the collapse of Jericho, the Israelites brought out silver and gold (Josh. $6: 19,24)$. Later reference is also made to an item of clothing that had been plundered $(7: 21,24)$.

(11) Lastly, we observe the important fact that explicit mention is made of the Israelite exodus from Egypt within the Jericho narrative itself. There Rahab is reported to have said to the two spies, "We have heard how the LORD dried up the water of the Red Sea before you when you came out of Egypt' (Josh. 2:10). In this connection, one further strong link is the fear on the part of the nations in response to this event. Each account in fact contains the sequence 'heard... melted...' (Exod. 15:14-15; Josh. 2:11; cf. also v. 24, which is a virtual citation from Exod. 15:1511).

Taken together these correspondences are too many and in some cases too close to attribute them to mere coincidence. Rather they speak of deliberate allusion on the part of one writer upon the earlier document or tradition.

11 Cf. L. Daniel Hawk, Joshua (Berit Olam; Collegeville, Minnesota: Liturgical Press, 2000): 44. 


\section{The Literary Framework}

The actuality of the foregoing connections is confirmed by an analysis of the larger literary framework in which each account is contained. Taking the Hebrew books in their final canonical shape, we see that the events from the exodus to the entry into the promised land form an extended inverted parallelism:

A Hebrews brought out of Egypt following Passover meal

B Crossing of the Red Sea / Manna commences

C Wilderness journey / testing

D Israel at Sinai

C' Wilderness journey / testing

B`Crossing the River Jordan / Manna ceases

A` Rahab brought out of Jericho following celebration of Passover

Scholars have previously noted certain unmistakable points of contact between the two halves of the structure. ${ }^{12}$ For instance, the first stage of the journey to Sinai (C) contains sections that have distinct counterparts in the journey from Sinai $\left(C^{\prime}\right)$. Amongst these may be included: grumbling against Moses and Aaron (Exod. 16:1-3; Num. 14:1-4), the provision of quail (Exod. 16:11-13; Num. 11:31-34), obtaining water from a rock that is struck (Exod. 17:1-7; Num. 20:113), and an episode involving Moses' father-in-law (Exod. 18:1-27; Num. 10:29-32). With respect to certain details there is, in fact, exact repetition. One example is the place where water issued from the rock, which is specifically named 'Meribah' in each section of the narrative (Exod. 17:7; Num. 20:13), though purporting to relate two different incidents. In some cases, lexical influence seems certain. One such example occurs in Exodus 16:2 and Numbers 16:41, which both read 'And the whole congregation of the children of Israel grumbled against Moses and Aaron'. Hence one current authority on the Pentateuch is able to describe the accounts of the journeys to and from Sinai as displaying a 'remarkable symmetry'. ${ }^{13}$

It may further be demonstrated that the water-crossing narratives (B and B') exhibit an unmistakable literary relationship. These parallels

12 E.g. David A. Dorsey, The Literary Structure of the Old Testament (Grand Rapids, Michigan: Baker, 1999): 101.

13 John H. Sailhamer, The Meaning of the Pentateuch: Revelation, Composition, and Interpretation (Downers Grove, Illinois: Inter-Varsity Press, 2009): 366. 
have also received recent scholarly attention. ${ }^{14}$ Besides the more obvious relationships involved at the general level, that is, the entire people of Israel crossing a body of water, there are numerous other linkages between the accounts. Here I will only give a brief summary of the chief of these. In both narratives the crossing is foretold by the leader (Exod. 14:16; Josh. 3:13). Both leaders receive instructions from God, beginning with the same emphatic, 'Now as for you [Iָ I- I(Exod. 14:16; Josh. 3:8). A divinely appointed instrument is involved in the removal of the waters, Moses' staff in one case, the ark in the other (Exod. 14:16; Josh. 3:11). These same two items also initiate the return of the waters. In both the waters are said to have 'stood in a heap [נ] ]' (Exod. 15:8; Josh. 3:13, 16). Following this the people pass over on 'dry ground' (Exod. 14:21, 23, 29; Josh. 3:17; 4:22), the two

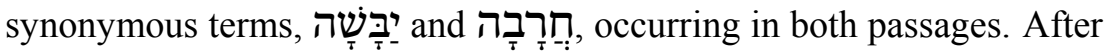
the crossing each account includes a statement concerning the enhanced attitude of the people towards their leader (Exod. 14:31; Josh. 4:14), the Joshua text explicitly drawing out the analogy with Moses at this point. Significantly, the direct speech here attributed to Joshua makes an overt comparison between the Red Sea and Jordan crossings (4:23). One consequence of each event is that the nations might 'know' something concerning Yahweh (Exod. 14:4; Josh. 4:24). Lastly, one other prominent feature is that subsequent to the crossing of the Red Sea into the wilderness the manna begins (Exod. 16:1-36), while after passing through the Jordan into the land the manna then comes to an end (Josh. 5:12).

Therefore, since the presence of structural parallelism and thematic correspondence is acknowledged for elements $\mathrm{B} / \mathrm{B}^{\prime}$ and $\mathrm{C} / \mathrm{C}^{\prime}$, it is reasonable to posit the same for $\mathrm{A} / \mathrm{A}^{\prime}$. Ample linguistic, thematic, and structural evidence exists therefore to establish the fact of a deliberately designed relationship between these two portions of the Hebrew Bible.

\section{Conclusions}

It remains now to offer a few remarks on the actual purport of the intertextual relationship that has been identified. Prominent in each text is the fact of deliverance in the face of impending destruction. The

14 E.g. Sarah Lebhar Hall, Conquering Character: The Characterization of Joshua in Joshua 1-11 (London: T \& T Clark, 2010): 54-58; Fishbane, Biblical Interpretation in Ancient Israel: 358-60. 
respective parties, Israel in Exodus and Rahab with her family in Joshua, are brought out from the judged land/city. When the latter is read in association with the earlier deliverance account it becomes apparent that the rescue of Rahab and her family is being presented as another exodus. It may be on a considerably smaller scale in comparison, yet it was an exodus, or a 'bringing out', nevertheless. Yet this was patently a wholly Gentile exodus. In keeping with the promise made to the Hebrew forefathers, that not just they themselves would possess the land, but that blessing would also come to those of other nations (Gen. 12:3; 18:18; 22:18; 26:4; 28:14), now a Gentile family received a blessing through Israel. In sparing the Canaanite family the Hebrews were in fact extending to Gentiles the covenant love, that they themselves enjoyed. Accordingly, as far as Rahab is concerned, the narrative ends with the statement that 'she lives in the midst of Israel to this day' (Josh. 6:25). She and those with her had, so to speak, become 'grafted in' to Israel. ${ }^{15}$

Finally, it is not impossible that the literary parallel was also intended to express something more. The name רָָָָ ('Rahab') bears some similarity to another Hebrew name רֵַב (also anglicised as 'Rahab'). This latter term is associated with the idea of 'pride' or 'insolence'. ${ }^{16}$ In certain passages of the Old Testament this is plainly a designation for the nation of Egypt. This is generally taken to be the case, for example, in Psalm 87:5 and Isaiah 51:9, but it is most obviously so in Isaiah 30:7, 'For Egypt offers help that is useless and empty, therefore I have called her Rahab the Do-Nothing' ${ }^{17}$ It is quite conceivable that the Hebrews, as well as detecting the parallels between Rahab's exodus and their own, appreciated the verbal pun implicit in her name. In their case they had been delivered from the Gentile (Egyptian) Rahab, insolent as she was, who suffered judgment. In the other case the Gentile (Canaanite) Rahab, in her evident submission to the divine purpose (cf. Josh. 2:9), herself was delivered from such judgment.

\footnotetext{
15 This situation calls to mind two comparable New Testament events-the essentially Jewish Pentecost of Acts 2, followed later by the 'Gentile Pentecost' of Acts 10 based upon the household of the Roman Cornelius.

16 F. Brown, S. R. Driver, and C. A. Briggs, A Hebrew and English Lexicon of the Old Testament (Oxford: Clarendon Press, 1953): 923a.

17 This is how the name has been translated in the NIV. More literally it calls her 'Rahab who sits still' (NRSV).
} 